\title{
The Evaluation of Suicide Attempts: Zonguldak Case
}

\author{
Hanifi Sever ${ }^{1}$, Muhammed Sever ${ }^{2}$ \\ ${ }^{1}$ Superintendent, Turkish National Police, Zonguldak, Turkey \\ ${ }^{2}$ Turkish Gendarmerie General Command, Kocaeli, Turkey \\ Email:drhanifisever@gmail.com
}

Received 23 March 2016; accepted 23 April 2016; published 26 April 2016

Copyright (C) 2016 by authors and Scientific Research Publishing Inc.

This work is licensed under the Creative Commons Attribution International License (CC BY).

http://creativecommons.org/licenses/by/4.0/

(c) (i) Open Access

\begin{abstract}
Suicide is the act of intentionally causing one's own death. Nonetheless not all suicide attempts result in death and studying the motives of these attempts poses great importance. The purpose of this study is to investigate the relation and differences between suicidal behaviors and suicidal ideation in Zonguldak city with regard to sociodemographic variables. Within this scope, "Suicide Ideation Scale", "Suicidal Behavior Scale" and descriptive methods were used on a sample including 439 individuals. The results of the study have shown that the relation among gender, suicidal behavior and suicide ideation is quite significant; women choose more attention-grabbing methods in their suicide attempts. In addition, age was seen as an important determinant. As one of the most remarkable results of the study, it can be concluded that due to rise in the rates of suicidal behavior, recurrent suicide attempt risk increases 19 times.
\end{abstract}

\section{Keywords}

\section{Suicide, Suicide Attempt, Suicidal Behavior, Suicidal Ideation}

\section{Introduction}

Suicide should be defined as intentionally or sudden self-murder. Internal feuds could lead one into inextricable psychological conditions which might result with suicide (Güçlü et al., 2003: p. 758; Page et al., 2006; Sayar et al., 2000).

There are three major perspectives on suicide. Freud defines suicide as a psychological phenomenon, while Durkheim regards it as a social phenomenon. Erkki, Markus and Henriksson on the other hand, present that suicide is welded from a psychiatric and genetic problem (Kim et al., 2006).

When describing it as a psychological phenomenon, some researchers mention that a state of self-conflict 
which is derived from offensive instincts and repression of drives is very effective (Köknel, 1987).

Regarding suicide as a social phenomenon, Emile Durkheim indicates that suicide is a result of societal factors. Therefore suicide types and rations might change in different societies (Deniz et al., 2001).

According to some studies, one person in every 42 seconds attempts suicide and 1000 people die every day due to suicide. In addition, it is remarkable that $15 \%$ of previously saved suiciders commit recurrent suicide (Kim et al., 2006; Jamison, 1999; Page et al., 2006).

Some studies reveal that gender is an important factor in suicidal behaviors (Zhang et al., 2005). Victims are mostly male in suicide cases resulted with death, while female individuals constitute majority in suicide attempts (Hawton, 2000; Johnson et al., 2000; Miller \& Glinski, 2000). Nonetheless, there are also some studies that state there is not any difference between men and women in terms of suicidal ideation (Kjøler \& Helweg-Larsen, 2000; Langhinrichsen-Rohling et al., 2004; Thomas et al., 2002).

Considering suicide methods of male and female participants, men mostly use rough and result oriented ways such as firearms or hanging themselves. Women however, prefer pharmaceutical overdose or jumping from heights (Lester, 1997).

The purpose of this study is to conduct a comparison of suicidal behavior and suicide ideation through suicide attempts in Zonguldak city.

\section{Methodology}

\subsection{Sample}

Firstly, a sample size was needed and a formula of $\left[n=N \cdot t^{2} \cdot p \cdot q / d^{2}(N-1)+t^{2} \cdot p \cdot q\right]$ was used to that end. The calculation revealed a sample size of 385. In 2013 and 2014, there had been a total of 1258 suicide attempts in Zonguldak city. Among them, 439 individuals accepted to participate in the study.

\subsection{Scales}

The study includes two scales regarding suicidal ideation and behavior. "Suicide Ideation Scale" was developed by Beck (1974) in 1973. This scale is applied to people who attempt suicide but survive and it helps to assess the severity of the suicide attempt. Validity and reliability of Suicide Ideation Scale in Turkey was assessed by Dilbaz et al. (1995) and test reliability and Cronbach's Alpha score was found $r=0.84$ and 0.83 respectively. The "Suicidal Behavior Scale" was developed by Linehan et al. (1981). Validityand reliability of this scale were assessed by Bayam et al. (1995) with reliability and Cronbach's Alpha scores $r=0.92$ and 0.73 respectively. The Suicidal Behavior Scale aims to determine the suicide plan and attempt of the individual.

\subsection{Procedure \& Data Analysis}

Voluntary individuals older than 18 with ended medical treatment were included in the study. Individuals that have either ongoing medical treatment, or reluctant to participate or younger than 18 were excluded. The answers of the participants to the questionnaire and scales were analyzed through SPSS (ver. 20.0) and their results were discussed. Participants' socio-demographic features were measured through frequency analysis. The relation between the scales used and socio-demographic variables were studied through correlation analysis. The relation between the scales and age groups were calculated through One Way-Anova analysis. In order to determine the source of the divergence between the age groups and scales, Tukey HSD test was applied. Tukey's test compares the means of every treatment to the means of every other treatment; that is, it applies simultaneously to the set of all pair wise comparisons and identifies any difference between two means that is greater than the expected standard error. The confidence coefficient for the set, when all sample sizes are equal, is exactly $1-\alpha$. Lastly, the variables that were thought be effective on suicide attempts, were tested by the binary logistic regression analysis.

\section{Results}

The socio-demographic features of the 439 participants are depicted on Table 1.

As seen on Table 1, a vast majority of the sample is women (80.9\%). $38.5 \%$ of the individuals that attempted suicide were 30 - 39 years old, while 11 - 18 and 19 - 29 age groups are also significant at this aspect. 
Table 1. Demographic findings of the study participants.

\begin{tabular}{|c|c|c|}
\hline Gender & $\mathbf{n}$ & $\%$ \\
\hline Male & 84 & 19.1 \\
\hline Female & 355 & 80.9 \\
\hline Total & 439 & 100 \\
\hline Age groups & $\mathbf{n}$ & $\%$ \\
\hline $11-18$ & 116 & 26.4 \\
\hline $19-29$ & 118 & 26.9 \\
\hline $30-39$ & 169 & 38.5 \\
\hline $40-49$ & 25 & 5.7 \\
\hline+50 & 11 & 2.5 \\
\hline Total & 439 & 100 \\
\hline Marital status & $\mathbf{n}$ & $\%$ \\
\hline Married & 355 & 80.9 \\
\hline Single & 84 & 19.1 \\
\hline Total & 439 & 100 \\
\hline The number of children & $\mathbf{n}$ & $\%$ \\
\hline 0 & 148 & 33.7 \\
\hline 1 & 98 & 22.3 \\
\hline 2 & 148 & 33.7 \\
\hline 3 & 33 & 7.5 \\
\hline 4 & 12 & 2.7 \\
\hline Total & 439 & 100 \\
\hline Education & $\mathbf{n}$ & $\%$ \\
\hline Illiterate & 20 & 4.6 \\
\hline Primary school & 282 & 64.2 \\
\hline High school & 122 & 27.8 \\
\hline University & 15 & 3.4 \\
\hline Total & 439 & 100 \\
\hline Income & $\mathbf{n}$ & $\%$ \\
\hline Yes & 84 & 19.1 \\
\hline No & 355 & 80.9 \\
\hline Total & 439 & 100 \\
\hline Occupation & $\mathbf{n}$ & $\%$ \\
\hline Unemployed & 343 & 78.1 \\
\hline Civil servant & 13 & 3 \\
\hline Worker & 64 & 14.6 \\
\hline Retired & 15 & 3.4 \\
\hline Other & 4 & 0.9 \\
\hline Total & 439 & 100 \\
\hline
\end{tabular}


80.9\% of the individuals that lived suicidal ideation and committed suicidal behavior were married and 33.7\% of the sample never had a child. More than half of the sample (64.2\%) is a graduate of elementary or secondary school, whereas high school graduates constitute $27.8 \%$. It is remarkable that $80.9 \%$ of the participants had no income and $78.1 \%$ were unemployed.

As seen on Table 2, a vast majority (80.4\%) of the individuals that committed suicide, has previous suicide experiences. Only 3.7\% of the participants committed suicide with death wish, while more than half (69.9\%) attempted suicide to attract other people's attention. $80 \%$ attempted suicide in order to give attitude to their partners or spouse. The rate of the individuals that committed suicide as a reaction against their families, life/fate, boss, governmental offices, or daughters/sons seems rather low.

Table 2. Suicide history of participants.

\begin{tabular}{|c|c|c|}
\hline Recurrent suicide attempt & $\mathbf{n}$ & $\%$ \\
\hline Yes (more than one suicide attempt) & 353 & 80.4 \\
\hline No (only one suicide attempt) & 86 & 19.6 \\
\hline Total & 439 & 100 \\
\hline The reason for the suicide attempt & $\mathbf{n}$ & $\%$ \\
\hline Taking attention & 307 & 69.9 \\
\hline Imposing themselves & 101 & 23 \\
\hline To die & 31 & 3.7 \\
\hline Total & 439 & 100 \\
\hline For whom the response & $\mathbf{n}$ & $\%$ \\
\hline Darling/spouse & 351 & 80 \\
\hline Family & 41 & 9.3 \\
\hline Life/destiny & 26 & 5.9 \\
\hline Boss & 13 & 3 \\
\hline State agency & 2 & .5 \\
\hline Their children & 6 & 1.4 \\
\hline Total & 439 & 100 \\
\hline The trait of suicide & $\mathbf{n}$ & $\%$ \\
\hline Hanging & 8 & 1.8 \\
\hline Jumping from somewhere & 62 & 14.1 \\
\hline Drug & 228 & 51.9 \\
\hline Wrist cutting & 84 & 19.1 \\
\hline Drowning in sea & 57 & 13 \\
\hline Total & 439 & 100 \\
\hline Suicide reason & $\mathbf{n}$ & $\%$ \\
\hline Unemployed & 58 & 13.2 \\
\hline The lack of expectation of life & 21 & 4.8 \\
\hline Love & 195 & 44.4 \\
\hline Disease & 50 & 11.4 \\
\hline Family pressure & 115 & 26.2 \\
\hline Total & 439 & 100 \\
\hline
\end{tabular}




\section{Continued}

\begin{tabular}{ccc}
\hline The way of suicide decision & $\mathbf{n}$ & $\mathbf{\%}$ \\
\hline Alcohol/narcotics drive me into suicide & 146 & 31 \\
Thinking about suicide for a long time & 92 & 21 \\
I decided to commit suicide suddenly & 102 & 23.2 \\
Disease & 15 & 3.4 \\
Decided to get fired & 94 & 21.4 \\
Total & 439 & 100 \\
\hline Why did they stop suicide? & $\mathbf{n}$ & $\mathbf{\%}$ \\
\hline Do not give up & 235 & 53.5 \\
Trust the police & 57 & 13 \\
Remember my friends & 15 & 3.4 \\
Decided that life is more valuable & 7 & 1.6 \\
Feared & 96 & 21.9 \\
Remember my family & 29 & 6.6 \\
Total & 439 & 100 \\
\hline Psychiatric treatment & $\mathbf{n}$ & $\mathbf{\%}$ \\
\hline Yes & 381 & 86.8 \\
No & 58 & 13.2 \\
\hline & 439 & 100 \\
\hline
\end{tabular}

When we look at the methods used in suicide action, more than half of the individuals (51.9\%) chose pharmaceutical overdose, 19.1\% preferred wrist cutting (exsanguination), 14.1\% jumped from heights, 13\% chose drowning in sea, and $1.8 \%$ hung themselves.

As seen on Table 2, 23.2\% of the participants suddenly decided to commit suicide, while $21 \%$ had suicidal ideation for a long time. Within the same scope, $31 \%$ stated that they made their mind for suicide under the influence of narcotic drugs.

$21.6 \%$ gave up their suicidal behaviors due to fear, and $13 \%$ abandoned suicide since they trusted the police officer that dealt with them. In connection with this, it is highly remarkable that more than half of the individuals (53.5\%) still mention about suicidal ideation.

Chi-square tests revealed that there is a statistically significant difference between the suicide methods of women and men ( $X^{2}$ : 8.636. $p$ : 0.042$)$. 39.1\% of the 30 - 39 age group and $7 \%$ of the $11-18$ age group ( $X^{2}$ : 1.639. $p: 0.032$ ) have previous suicide experiences. When focused on age groups and suicide reasons, some differences were determined ( $X^{2}: 28.685 . p$ : 0.001). Individuals under 18 committed suicide rather to "attract attention" (66.1\%), while 30 - 39 age group to did the same thing to "make themselves accepted". $45.2 \%$ of the participants under 18 cut their wrists, $46.2 \%$ of the 19 - 29 age group took overdose of drugs, and $59.7 \%$ of the 30 39 age group jumped from heights. These data show that there is a statistically significant difference between age groups and suicide methods ( $\left.X^{2}: 154.861 . p: 0.000\right)$.

$62.9 \%$ of the individuals with previous suicide experiences are elementary school graduates, while majority of the participants without previous suicide experiences are mostly high school graduates (69.8\%). The ones that really attempted suicide to die are mostly high school graduates (80.6\%) as well. On the other hand, the individuals that attempted suicide in order to "attract attentions" (66.8\%) and "make themselves accepted" (70.3\%) are mostly elementary school graduates. There is a statistically significant difference between cause of suicide and education status ( $X^{2}: 40.302$. $\left.p: 0.000\right)$.

There is also a statistically significant difference between income status and cause of suicide $\left(X^{2}: 24.641 . p\right.$ : 0.000). $34.5 \%$ and $32.1 \%$ of the participants with recurring revenues committed suicide due to parental pressures and failed love affairs respectively. On the other hand, $46.8 \%$ of the individuals without regular income attempted suicide due to parental pressure. 
The average of the Suicidal Behavior Scale points was found $2.65 \pm 1.49$. The scale is 5-point Likert and scoring is from $0-4$. According to the scale, as long as average rises, the seriousness of the suicidal behavior rises in the same way. At this end, the level of suicidal behavior in the suicide cases of the current study seems relatively low, and most of the participants (69.9\%) attempted suicide in order to "attract attentions" and "make other people do his wishes".

The average of the Suicide Ideation Scale which tests suicidal ideation was found $9.57 \pm 2.78$. With scores from 3 - 16, the number of individuals thinking of suicide within the soonest time stayed well below the average, according to this scale.

As a next step of the study, correlation between sociodemographic variables and Suicidal Behavior and Suicide Ideation Scales were researched. Most of the variables had negatively significant correlation with the scales only except for suicidal ideation and income relation which is insignificant (Table 3).

Table 4 shows a significant difference between Suicidal Behavior and Suicide Ideation Scales and age groups (One Way-Anova). According to the table, suicide ideation and suicidal behavior peak up at the 30 - 39 age group and decline rapidly after 40 .

In order to determine the differences between Suicidal Behavior and Suicide ideation and age, Tukey HSD Test was conducted (Table 5). In terms of suicide ideation, there was not a difference between adolescents (11 18 years old) and young adults (19 - 29 years old) $(p=0.958)$, while a significant difference was found between

Table 3. Suicide behavior, ideation, and some variables.

\begin{tabular}{ccccccc}
\hline \multirow{2}{*}{ Variables } & \multicolumn{3}{c}{ Suicidal behavior } & \multicolumn{3}{c}{ Suicidal ideation } \\
\cline { 2 - 7 } & $\mathrm{n}$ & $\mathrm{r}$ & $p$ & $\mathrm{n}$ & $\mathrm{r}$ & $p$ \\
\hline Age & 439 & $-0.512^{* *}$ & 0.000 & 439 & $-0.436^{* *}$ & 0.002 \\
The number of children & 439 & $-0.453^{* *}$ & 0.003 & 439 & $-0.359^{* *}$ & 0.000 \\
Income & 439 & $-0.399^{* *}$ & 0.000 & 439 & $-0.541^{* *}$ & 0.235 \\
\hline
\end{tabular}

Table 4. Suicide behavior, ideation, and age.

\begin{tabular}{cccccccc}
\hline \multirow{2}{*}{ Variables } & \multicolumn{7}{c}{ Age } \\
\cline { 2 - 8 } & $11-18$ & $19-29$ & $30-39$ & $40-49$ & +50 & F & $p$ \\
\hline Suicidal behavior & $2.42 \pm 0.732$ & $3.28 \pm 1.08$ & $3.71 \pm 0.899$ & $2.28 \pm 0.763$ & $1.58 \pm 0.506$ & 40.598 & 0.000 \\
Suicidal ideation & $8.78 \pm 0.866$ & $11.31 \pm 0.938$ & $13.73 \pm 0.874$ & $7.32 \pm 0.999$ & $6.75 \pm 0.806$ & 33.676 & 0.000 \\
\hline
\end{tabular}

Table 5. Differences between suicide behavior, ideation, and age.

\begin{tabular}{|c|c|c|c|c|c|}
\hline \multirow[b]{2}{*}{ Year } & \multirow[b]{2}{*}{ Year } & \multicolumn{2}{|c|}{ Suicidal behavior } & \multicolumn{2}{|c|}{ Suicidal ideation } \\
\hline & & Mean Dif. & $p$ & Mean Dif. & $p$ \\
\hline \multirow{3}{*}{$11-18$} & $19-29$ & 0.692348 & 0.002 & 0.00459 & 0.958 \\
\hline & $30-39$ & 0.903132 & 0.000 & $-0.57855^{*}$ & 0.001 \\
\hline & $40-49$ & 0.072445 & 0.993 & -0.23297 & 0.526 \\
\hline \multirow{3}{*}{$19-29$} & $11-18$ & -0.028928 & 0.997 & $0.96842^{*}$ & 0.008 \\
\hline & $30-39$ & 0.874204 & 0.000 & $-0.58314^{*}$ & 0.003 \\
\hline & $40-49$ & 0.663420 & 0.009 & -0.23755 & 0.585 \\
\hline \multirow{3}{*}{$30-39$} & $11-18$ & -0.903132 & 0.000 & $0.57855^{*}$ & 0.001 \\
\hline & $19-29$ & -0.874204 & 0.000 & $0.58314^{*}$ & 0.003 \\
\hline & $40-49$ & -0.210784 & 0.788 & 0.34559 & 0.320 \\
\hline \multirow{3}{*}{$40-49$} & $11-18$ & -0.692348 & 0.002 & 0.23297 & 0.526 \\
\hline & $19-29$ & -0.663420 & 0.009 & 0.23755 & 0.585 \\
\hline & $30-39$ & 0.210784 & 0.787 & -0.34559 & 0.320 \\
\hline
\end{tabular}


the two age groups with regard to suicidal behavior $(p=0.002)$. Likewise a difference in suicidal behavior $(p=$ $0.009)$ and suicide ideation ( $p=0.585)$ was seen between young adults (19 - 29 years old) and elders (40 - 49 years old).

The variables that might be effective on suicide attempts were tested through univariate binary logistic regression analysis. A significant model was found between suicidal behavior and education status, income and occupational variables. As total score of suicidal behavior increases, the risk of suicide rises 19.179 times (Table 6).

\section{Discussion}

There are some studies that state there is not any difference between men and women in terms of suicidal ideation (Kjøler \& Helweg-Larsen, 2000; Langhinrichsen-Rohling et al., 2004; Thomas et al., 2002). According to the current study, gender cannot be a significant precursor of suicide attempts $(p=0.375)$.

Our study revealed similar results with Lester (1999)'s survey. Men and women participants chose different methods in their suicide attempts $\left(X^{2}\right.$ : 8.636. $p$ : 0.042$)$. At this end, male individuals mostly hung themselves or drowned in sea, while women cut their wrists or took overdose of drugs.

Özel et al. (2008) indicated that 50\% of the sample with previous suicide experiences was 21 - 30 years old, $70.8 \%$ was female and $47.9 \%$ was elementary and secondary school graduates, regarding Kütahya province. When suicide reasons were considered in the same study, 28.7\% of the sample asserted "familial issues", $26.7 \%$ referred to "depression", 9.3\% ascribed "serious diseases" and 8.4\% mentioned about "argue with partner/ spouse". Deniz et al. (2001) stated that $76.6 \%$ of the suicide attempts in Batman province was committed by women.34.8\% of the women was 18 - 21 years old, while $33.3 \%$ of the men was 31 - 40 years old. Same study revealed that $51.1 \%$ of the sample took overdose of drugs, $5.6 \%$ jumped from heights, and $6.7 \%$ hung themselves. With regard to suicidal motives, $12.9 \%$ committed suicide due to psychological reasons, $6.9 \%$ due to economic issues, and $5 \%$ due to familial pressure.

Nordström et al. (1995) studied 1573 patients with suicidal case histories in Karolinka Hospital from 19811988. Findings of the study indicated that two thirds of the sample was women, average age was 35, recurrent suicide risk was $8.3 \%$ for men and $4.3 \%$ for women. Nordström et al. (1995) concluded that as long as women's age rise, suicide risk increases in the same direction. The current study revealed that suicide attempts are rather concentrated on 30 - 39 and lower age groups. In the same aspect, a sharp drop was seen in suicide attemptes at 40 and older ages. Majority of the sample was married and had a low educational status, and this shows a similarity with other studies. Unemployment and irregular income or nonrevenue also attract attentions as serious issues.

Most of the recurrent suiciders are elementary school graduates. It must be noted that educational status is an important criteria in suicidal behaviors.

When we focused on the individuals with previous suicide attempts (80.9\%) and the ones that really wanted to die (3.7\%), it can be stated that most of the participants attempted suicide in order to attract attentions, punish or to make somebody in sorrow. More than half of the participants (53.5\%) stated that they would commit suicide again. Considering only 3.7\% wanted to die, such intense recurrent suicide ideation seems meaningful; individuals will likely continue to prefer suicide attempts as a tool to attract attentions of their families/spouses

Table 6. Binary logistic regression analysis of suicide behavior.

\begin{tabular}{|c|c|c|c|c|c|c|c|}
\hline \multicolumn{8}{|c|}{ Regression model } \\
\hline & B & S.E. & $p$ & Odds Ratio & -2 Log Likelihood & $\begin{array}{c}\text { Cox \& Snell } \\
\text { R Square }\end{array}$ & $\begin{array}{c}\text { Nagelkerke } \\
\text { R Square }\end{array}$ \\
\hline Age & -0.152 & 0.138 & 0.268 & 0.756 & 95.829 & 0.017 & 0.023 \\
\hline Gender & 0.156 & 0.478 & 0.375 & 0.859 & 97.041 & 0.000 & 0.000 \\
\hline Education & -0.173 & 0.329 & 0.000 & 4.393 & 82.336 & 0.134 & 0.411 \\
\hline Income & -0.755 & 0.245 & 0.000 & 1.220 & 87.607 & 0.136 & 0.187 \\
\hline Occupation & 2.828 & 0.064 & 0.004 & 16.91 & 72.280 & 0.309 & 0.267 \\
\hline Suicidal behavior & 2.689 & 0.985 & 0.003 & 19.179 & 16.896 & 0.489 & 0.482 \\
\hline
\end{tabular}


and get their wishes accepted.

In accordance with the information from Suicidal Behavior Scale, seriousness of the participants seems very low. This shows that they choose some rituals to drive attentions of their families/spouses. The Suicide Ideation Scale which determines the suicide ideation in a close period of time revealed that participants that committed suicide lately are well below the average. Although the individuals that aim recurrent suicide constitute half of the sample, the Suicide Ideation Scale declines this rate.

When focused on whether suicidal behavior occurred suddenly or as a result of a certain process, we could not find any statistical significant difference. However suicidal behavior rate under the effect of narcotic substances or alcohol is high.

A minority (13\%) of the participants stated that police dissuaded them from suicide. At this end, social workers, psychologists or professional negotiators might be more useful in such cases.

A significant model was determined between suicidal behavior and variables of educational background, income status and occupation. As total score of suicidal behavior increases, the risk of suicide rises 19.179 times.

\section{Conclusion}

Suicide is the act of intentionally causing one's own death due to a certain reason. There are a number of factors that cause suicide. Future sociological and psychological researches on these factors have great importance. There are some possible future research areas to take the results of this study further. First it may include separate and combined studies on individual, social, environmental and psychological factors that cause suicide. Another research area should focus on law enforcers' point of view towards suicide or suicide attempt cases and their courses of action on such incidents. Finally, society's attitude towards suicide throughout history must be well understood.

The individuals that participated in this study generally preferred suicide as a tool in order to suppress their social environment for a certain reason or attract attentions of their families/spouses. Suicide methods of men and women were different than each other, while men's methods were decisively fatal.

The negative relation between educational background and suicide is very significant. In addition, age is also an important factor: a sharp drop was seen in suicide attempts at 40 and older ages.

Suicidal behavior scale and suicide ideation scale have shown that participants of the study were not decisively determined to suicide. One of the most important results of the study reveals that as total score of suicidal behavior increases, the risk of suicide rises 19.179 times.

\section{References}

Bayam, G., Dilbaz, N., Bitlis, V., Holat, H., \& Tüzer, T. (1995). Suicidal Behavior, Depression, Desperation and Suicidal Ideation Relation: A Study on Validity and Reliability of Suicidal Behavior Scale. Kriz Dergisi, 3, 223-225. http://dx.doi.org/10.1501/Kriz_0000000098

Beck, A. T., Schuyler, D., \& Herman, I. (1974). Development of Suicidal Intent Scales. Charles Press Publishers.

Deniz, İ., Günindi, E. A., İldeş, N., \& Türkarslan, N. (2001). A Research on the Official Registries of Suicide and Suicide Attempts in Batman Province from 1995-2000. Aileve Toplum, 1, 4-24.

Dilbaz, N., Holat, H., Bayam, G., Tüzer, T., \& Bitlis. V. (1995). Validity and Reliability of Suicide Intent Scale. 31th National Psychology Congress (Ulusal Psikiyatri Kongresi), 27-30.

Güçlü, B., Uzun, E., Uzun, S., \& Yolsal, H. (2003). Dictionary of Philosopy (Felsefe Sözlügü). Ankara: Bilimve Sanat Publishing.

Hawton, K. (2000). Sex and Suicide. British Journal of Psychiatry, 177, 484-485. http://dx.doi.org/10.1192/bjp.177.6.484

Jamison, K. R. (1999). Night Falls Fast: Understanding Suicide. New York: Random House Inc.

Johnson, G. R., Krug, G., \& Potter, L. B. (2000). Suicide among Adolescents and Young Adults: A Cross-National Comparison of 34 Countries. Suicide and Life-Threatening Behavior, 30, 74-82.

Kim, M. D., Hong, S. C., Lee, S. Y., Kwak, Y. S., Lee, C. I., Hwang, S. W., Shin, T. K., Lee, S. M., \& Shin, J. N. (2006). Suicide Risk in Relation to Social Class: A National Register-Based Study of Adult Suicides in Korea 1999-2001. International Journal of Social Psychiatry, 52, 138-151. http://dx.doi.org/10.1177/0020764006061254

Kjøler, M., \& Helweg-Larsen, M. (2000). Suicidal Ideation and Suicide Attempts among Adult Danes. Scandinavian Journal of Public Health, 28, 54-61. http://dx.doi.org/10.1177/140349480002800110

Köknel, Ö. (1987). Compelled Human: Stress in the Age of Anxiety. Istanbul: Altın Kitaplar Publishing. 
Langhinrichsen-Rohling, J., Arata, C., Bowers, D., O’Brien, N., \& Morgan, A. (2004). Suicidal Behavior, Negative Affect, Gender, and Self-Reported Delinquency in College Students. Suicide and Life-Threatening Behavior, 34, $255-267$.

Lester, D. (1997). Gender Differences in Suicidal Behavior. Making Sense of Suicide. Philadelphia, PA: The Charles Press, Publishers Inc.

Linehan, M. M., \& Nielsen, S. L. (1981). Assessment of Suicidal Ideation and Parasuicide: Hopelessness and Social Desirability. Journal of Consulting and Clinical Psychology, 49, 773-775. http://dx.doi.org/10.1037/0022-006X.49.5.773

Miller, A. L., \& Glinski, J. (2000). Youth Suicidal Behavior: Assessment and Intervention. Journal of Clinical Psychology, 56, 1131-1152. http://dx.doi.org/10.1002/1097-4679(200009)56:9<1131::AID-JCLP3>3.0.CO;2-8

Nordström, P., Samuelsson, M., \& Asberg, M. (1995). Survival Analysis of Suicide Risk After Attempted Suicide. Acta Psychiatrica Scandinavica, 91, 336-340. http://dx.doi.org/10.1111/j.1600-0447.1995.tb09791.x

Özel, A., Keser, N., \& Köksal, E. (2008). Gender, Education Levels and Geographic Distribution of Suicide and Suicide Attempts: Case of Kutahya Province (İntihar Veİntihara Teşebbüs Eden Bireylerin Cinsiyeti. Eğitim Düzeylerive Coğrafi Dağılımları: Kütahya Şehri Örneği). Journal of Eastern Geography (Doğu Coğrafya Dergisi), 13, 231-250.

Page, R. M., Yanagishita, J., Suwanteerangkul, J., Zarco, E. P., Mei-Lee, C., \& Miao, N. F. (2006). Hopelessness and Loneliness among Suicide Attempters in School-Based Samples of Taiwanese. Philippine and Thai Adolescents, 27, 583-598.

Sayar, M. K., Öztürk, M., \& Acar, B. (2000). Psychological Factors in Adolescents with Suicide Histories Due to Pharmaceutical Overdose (Aşırı Dozda İlaç Alımıyla İntihar Girişiminde Bulunan Ergenlerde Psikolojik Etkenler). Bulletin of Clinical Psychopharmacology (Klinik Psikofarmakoloji Bülteni), 10, 133-138.

Thomas, H. V., Crawford, M., Meltzer, H., \& Lewis, G. (2002). Thinking Life Is Not Worth Living. Social Psychiatry and Psychiatric Epidemiology, 37, 351-356. http://dx.doi.org/10.1007/s00127-002-0556-5

Zhang, J., McKown, R. E., Hussey, J. R., Thompson, S. J., \& Woods, J. R. (2005). Gender Differences in Risk Factors for Attempted Suicide among Young Adults: Findings from the Third National Health and Nutrition Examination Survey. Annuals of Epidemiology, 15, 167-174. http://dx.doi.org/10.1016/j.annepidem.2004.07.095 